\title{
Mineral carbonation at Venetia and Gahcho Kué diamond mines: Characterization of the highly reactive clay fraction
}

\author{
NINA ZEYEN ${ }^{1}$, BAOLIN WANG ${ }^{2}$, SIOBHAN WILSON ${ }^{2}$, \\ CARLOS PAULO $^{3}$, AMANDA R. STUBBS ${ }^{3}$, IAN M. \\ POWER $^{3}$, CONNOR TURVEY $^{4}$ AND GREGORY DIPPLE $^{5}$ \\ ${ }^{1}$ University of Alberta - EAS \\ ${ }^{2}$ University of Alberta \\ ${ }^{3}$ Trent University \\ ${ }^{4}$ University of British Columbia \\ ${ }^{5} \mathrm{UBC}$ \\ Presenting Author: zeyen@ualberta.ca
}

Carbonation reaction is a natural process that regulates atmospheric $\mathrm{CO}_{2}$ levels by formation of carbonates, which constitute the largest reservoir for carbon on Earth [1]. Accelerated mineral carbonation via enhanced weathering is a carbon dioxide removal (CDR) technology that can be employed by industries, such as mining, that generate alkaline processed materials that are reactive to $\mathrm{CO}_{2}$. The crystal structure, crystal chemistry, surface area and reactivity of a target silicate or hydroxide mineral are key controls on the conversion of $\mathrm{CO}_{2}$ into solid carbonates. Whereas serpentines, olivines and brucite have been extensively studied, little is known about the nature and reactivity of smectite(s) for $\mathrm{CO}_{2}$ sequestration.

Here, we present the mineralogy and reactivity of different facies of processed kimberlites and ore from Venetia (South Africa) and Gahcho Kué (Canada) diamond mines. Highly reactive brucite $\left[\mathrm{Mg}(\mathrm{OH})_{2}\right]$ is typically absent in samples $(\mathrm{n}=22)$, necessitating the development of new strategies for mineral carbonation. Conversely, smectites constitute an abundant fraction from many diamond mines including the two studied mines [2] where smectite is distributed as a fine matrix within processed kimberlites and ore. The smectite from both mines is saponite, a trioctahedral, Mg-rich and Al-, Ca- and Fe-bearing member of the group. Cation exchange capacity of the samples was performed using ammonium acetate solution (1M) at ambient temperature and ambient $\mathrm{CO}_{2}$. A positive correlation between the cation exchange capacity and the smectite content of the samples suggests that smectite is the most reactive phase within these ultramafic rocks and that it can be used as a source of $\mathrm{Mg}, \mathrm{Ca}$ and $\mathrm{Fe}$ for carbonation reactions. Importantly, carbonates are abundant in Venetia ore, and the ore from many other diamond mines, requiring that mineralization $\mathrm{CDR}$ strategies (e.g., acid leaching, cation exchange) be tailored to the mineralogy of each mine to avoid $\mathrm{CO}_{2}$ release due to primary calcite dissolution. A framework for selecting technologies that are best suited to optimize carbonation of processed kimberlite on the basis of mineralogy will be further discussed.

[1] Berner R.A. et al., (1983) American Journal of Science, 283, 641-683

[2] Mervine E.M. et al., (2018) Mineralogy and Petrology 112, S755-S765 